\title{
АНАЛІЗ ТРАНСПОРТНО-ТЕХНОЛОГІЧНОГО ЦИКЛУ ТРАНСПОРТУВАННЯ РІДКОГО ДОМЕННОГО ШЛАКУ ДО ВІДДІЛЕННЯ ПЕРЕРОБКИ
}

У зв'язку з розвитком сучасних високопродуктивних технологій в металургії $i$ необхідністю врахування нових вимог, виконано аналіз транспортно-технологічного ичклу транспортування рідкого доменного шлаку до відділення переробки. Визначено фактичні величини показників основних технологічних операцій $i$ зіставлено 3 нормативними значеннями. Виявлено недоліки в транспортному обслуговуванні илаковозної сторони доменного виробництва

Ключові слова: доменне виробництво, илак, промисловий транспорт, транспортування, транспортне обслуговування, транспортно-технологічний цикл

Постановка проблеми. Доменне виробництво спільно 3 агломераційним є першим переділом в чорній металургії. Доменне виробництво включає три етапи: підготовка і подача шихтових матеріалів; виплавка чавуну в доменних печах і прибирання продуктів плавки.

Одним 3 важливих і відповідальних процесів металургійних підприємств $є$ прибирання рідкого шлаку і транспортування його на переробку. У світовій практиці відомі 2 способи прибирання і транспортування рідкого (розплавленого) шлаку:

- використання залізничних шлаковозів (шлакових чаш з чавуну або сталі) місткістю 11, 16 і 16,5 м³ для зливу і транспортування шлаку в цех (відділення) переробки доменних шлаків (доменні печі ємністю до $5000 \mathrm{~m}^{3}$ );

- 3 використанням технології придоменної (припічної) грануляції, при якій розплавлений шлак за спеціальним жолобом подається на установку придоменної грануляції (доменні печі ємністю 5000-5500 м³ і більше). Доменна піч має дві установки, які розташовані з протилежних сторін ливарного двору, при цьому кожна установка має дві автономні робочі лінії. Установки бувають двох типів: 3 грануляцією струменями води і 3 гідроекранним гранулятором.

Характерною особливістю матеріального потоку рідкого доменного шлаку, при використанні залізничного транспорту, є відсутність фази проміжного складування на стадії його зародження (безпосередній злив шлаку з доменної печі в шлаковоз).

Відсутність проміжного складування рідкого доменного шлаку вимагає підвищеної надійності транспортного обслуговування. 3 цією метою для безперебійної роботи доменного виробництва і виробничо-транспортної системи підприємства в цілому, задіяні резервні ресурси транспорту, що представляють собою додатковий вагонний і локомотивний парки, комплекс транспортних комунікацій і пристроїв.

Крім того, на ділянці виробничо-транспортного комплексу (доменний цех - цех (відділення) переробки доменних шлаків) резервна кількість тягового рухомого складу та шлаковозів не завжди забезпечують нормальний ритм основного виробництва.

Наявність резервних ресурсів транспортної складової, зниження продуктивності агрегатів, аварійність 3 причин збоїв в роботі транспорту обумовлюють значні транспортні витрати при обслуговуванні доменних цехів і збільшують загальну собівартість доменного виробництва.

Обсяг транспортної роботи на цій ділянці залежить від безлічі факторів: обсягу, продуктивності і регламенту роботи доменних печей, технології доменного виробництва, призначення вантажопотоку, технології обробки чавуну, планувального рішення доменного

Режим доступу: http://sap.pstu.edu 
$2019 \mathrm{p}$.

\section{Транспортні технології}

Вип. 20

цеху, його колійного розвитку та ін. Особливістю транспортного обслуговування доменного виробництва $\epsilon$ те, що розміри вантажопотоків непропорційні розмірам вагоно- $\mathrm{i}$ поїздопотоків. Тобто, на перевезеннях рідкого чавуну і шлаку, як резерв, завжди потрібна додаткова кількість вагонів (чаш), локомотивів та інших ресурсів транспорту. При цьому, кількість резервних транспортних одиниць істотно більше, ніж на інших перевезеннях.

Для вдосконалення процесу вантажопереробки рідкого доменного шлаку потрібно системно проаналізувати процес транспортного обслуговування доменного виробництва та кількісно оцінити витрати виробництва і транспорту. Це є досить складним завданням і його необхідно вирішувати в кілька етапів - аналіз витрат часу на транспортно-технологічні операції, визначення показників транспортної роботи, аналіз економічних витрат транспорту і виробництва.

На початковому етапі дослідження необхідно визначити тривалість технологічних операцій і провести аналіз транспортно-технологічного циклу транспортування рідкого доменного шлаку.

Аналіз останніх досліджень і публікацій. В даний час накопичена значна кількість матеріалу з питань підвищення ефективності транспортного обслуговування металургійних підприємств i роботи промислового транспорту. В області перевезень гарячих (розплавлених) вантажів розроблені теоретичні основи і методи оптимізації взаємодії промислового транспорту з виробничими підрозділами $[1,2]$, розглянуті питання вдосконалення технології внутрішньовузлових перевезень [3], питання моніторингу внутрішньозаводського транспортування [4-6]. Питання аналізу процесу перевезення, як єдиного транспортно-технологічного циклу в умовах динаміки виробничо-транспортного процесу, в розглянутих джерелах лише позначені і належного розвитку не отримали.

У той же час, в сучасних умовах дедалі настійніше потрібна розробка методів $\mathrm{i}$ аналітичних моделей, які б дозволили виконати конкретні розрахунки, пов'язані з аналізом, синтезом і оптимізацією систем управління процесом матеріалоруху підприємств. При цьому, в першу чергу необхідні методи і моделі, що поєднують кілька функцій і дозволяють оптимізувати витрати в ланцюзі матеріалоруху при фазовій трансформації в пунктах переробки вантажів.

Мета роботи. Метою цієї роботи $\epsilon$ аналіз транспортно-технологічного циклу транспортування рідкого доменного шлаку в цех (відділення) переробки. Для цього необхідно зіставити існуючі й дійсні графіки випуску шлаку і провести оцінку технологічних графіків обороту шлаковозних ковшів, а також виявити види і тривалість позапланових простоїв рухомого складу.

Виклад основного матеріалу. Виробництво чавуну $є$ складним і безперервним процесом, який охоплює численні технологічні і транспортні операції, що вимагає надійної роботи транспорту по прибиранню продуктів плавки, зокрема шлаку. Перевезення доменного шлаку характеризується високою температурою (понад $800{ }^{\circ} \mathrm{C}$ ), великою вантажопідйомністю рухомого складу (25-40 т і більше), складністю організації транспортного процесу.

Транспортно-технологічний цикл транспортування рідкого доменного шлаку $є$ комплексом закінчених технологічних $\mathrm{i}$ транспортних операцій, що мають певну послідовність і тривалість виконання, а також забезпечують виробничий процес доменних печей в заданих регламенті і ритмі їх роботи. Основні операції, що входять до обороту шлаковозного составу: очікування постановки чаш під доменними печами, розстановка ковшів (чаш) під печами, очікування наливу шлаку, наповнення чаш, очікування заявки на прибирання, прибирання шлаковозів $з$ печі, формування составу (потягу), випробування автогальм, транспортування до ЦДШ (на гранустановку), подача составу на грануляцію, злив

Режим доступу: http://sap.pstu.edu 
$2019 \mathrm{p}$.

\section{Транспортні технології}

Вип. 20

шлаку, транспортування на яму, вибивання чаш, очищення гребінок від шлаку, подача на обприскування, обприскування чаш, змащування черв'ячної передачі i опробування автогальм, транспортування в ДЦ. Крім перелічених технологічних операцій можуть виконуватись додаткові операції, пов'язані 3 виведенням та введенням несправних шлаковозів, а також операції з обробки інших вагонів, які можуть бути у составі. Наприклад, вагони зі зварювальним шлаком з прокатних цехів.

Транспортно-технологічна схема доменного виробництва наведена на рис. 1, а нормативи часу на оборот шлаковозних составів - на рис. 2-4.

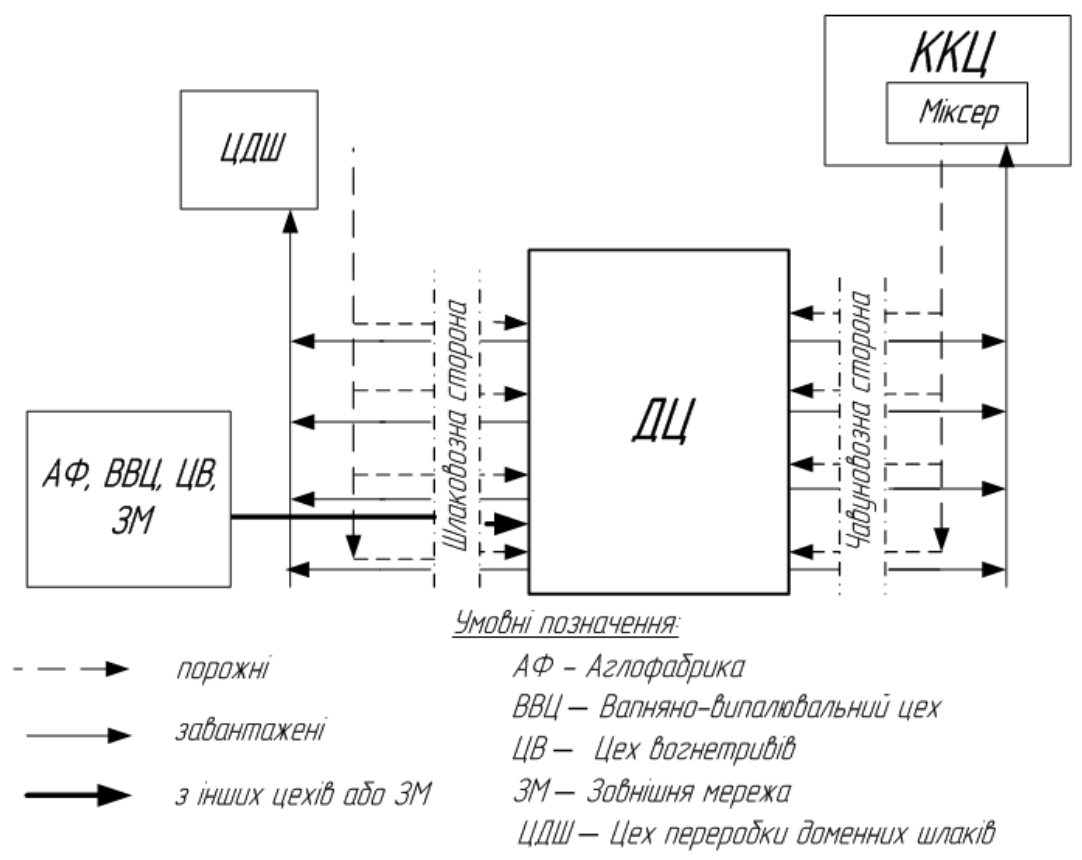

Рисунок 1 - Транспортно-технологічна схема доменного виробництва

Дані за тимчасовими інтервалами і тривалості технологічних операцій отримані шляхом хронометричних і натурних досліджень, а також використовувалися звітні дані одного з металургійних комбінатів.

Аналіз отриманих результатів показав, що фактична тривалість (час) обороту шлаковозних ковшів $\left(T_{\text {об }}^{i}\right)$ складається з нормативної тривалості виконання технологічних операцій $\left(T_{i}^{j}\right)$ і ненормативних простоїв $\left(t_{i}^{j}\right)$.

$$
T_{\text {oб }}^{i}=T_{i}^{j}+t_{i}^{j} \text {. }
$$

Нормативна тривалість виконання технологічних операцій (норматив часу на оборот шлаковозних составів) визначається за графіками, наведеними на рис. 2-4.

Величина обороту шлаковозного составу без виконання робіт з виведення і введення в експлуатацію ремонтних шлакових чаш і обробки зварювальних шлаків:

$$
T_{\text {об }}^{1}=T_{1}^{1}+T_{2}^{1}+T_{3}^{1} \ldots+T_{18}^{1}=\sum_{i=1}^{18} T_{i}^{l},
$$


$2019 \mathrm{p}$.

\section{Транспортні технології}

Вип. 20

Величина обороту шлаковозного составу з урахуванням виконання робіт з виведення $\mathrm{i}$ введення в експлуатацію ремонтних шлакових чаш при технічній несправності:

$$
T_{o \sigma}^{2}=T_{1}^{2}+T_{2}^{2}+T_{3}^{2} \ldots+T_{19}^{2}=\sum_{i=1}^{19} T_{i}^{2},
$$

Величина обороту шлаковозного составу з урахуванням обробки зваршлаків:

$$
T_{\text {об }}^{3}=T_{1}^{3}+T_{2}^{3}+T_{3}^{3} \ldots+T_{19}^{3}=\sum_{i=1}^{19} T_{i}^{3},
$$

де $T_{i}^{l}, T_{i}^{2}, T_{i}^{3}$ - відповідно тривалість $i$-ї технологічної операції для кожного з 3-х технологічних графіків обороту шлаковозного составу (рис. 2-4).

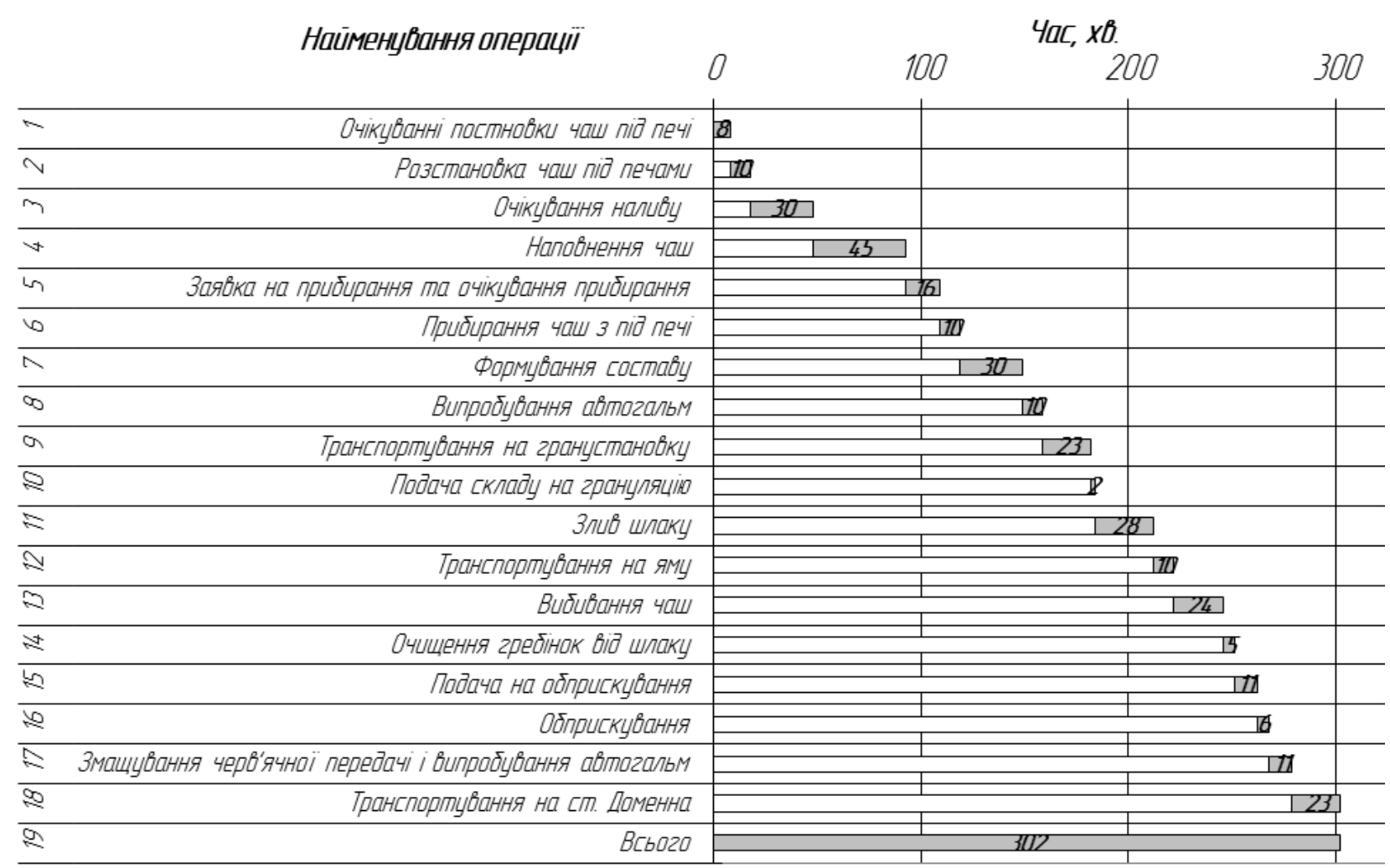

Рисунок 2 - Норматив часу на повний оборот шлакових чаш на ділянці ДЦ-ЦДШ без виконання робіт з виведення і введення в експлуатацію ремонтних шлакових чаш і обробки вагонів з іншими вантажами

Режим доступу: http://sap.pstu.edu 


\section{Наука та виробництво}

$2019 \mathrm{p}$.

Вип. 20

\section{Транспортні технології}

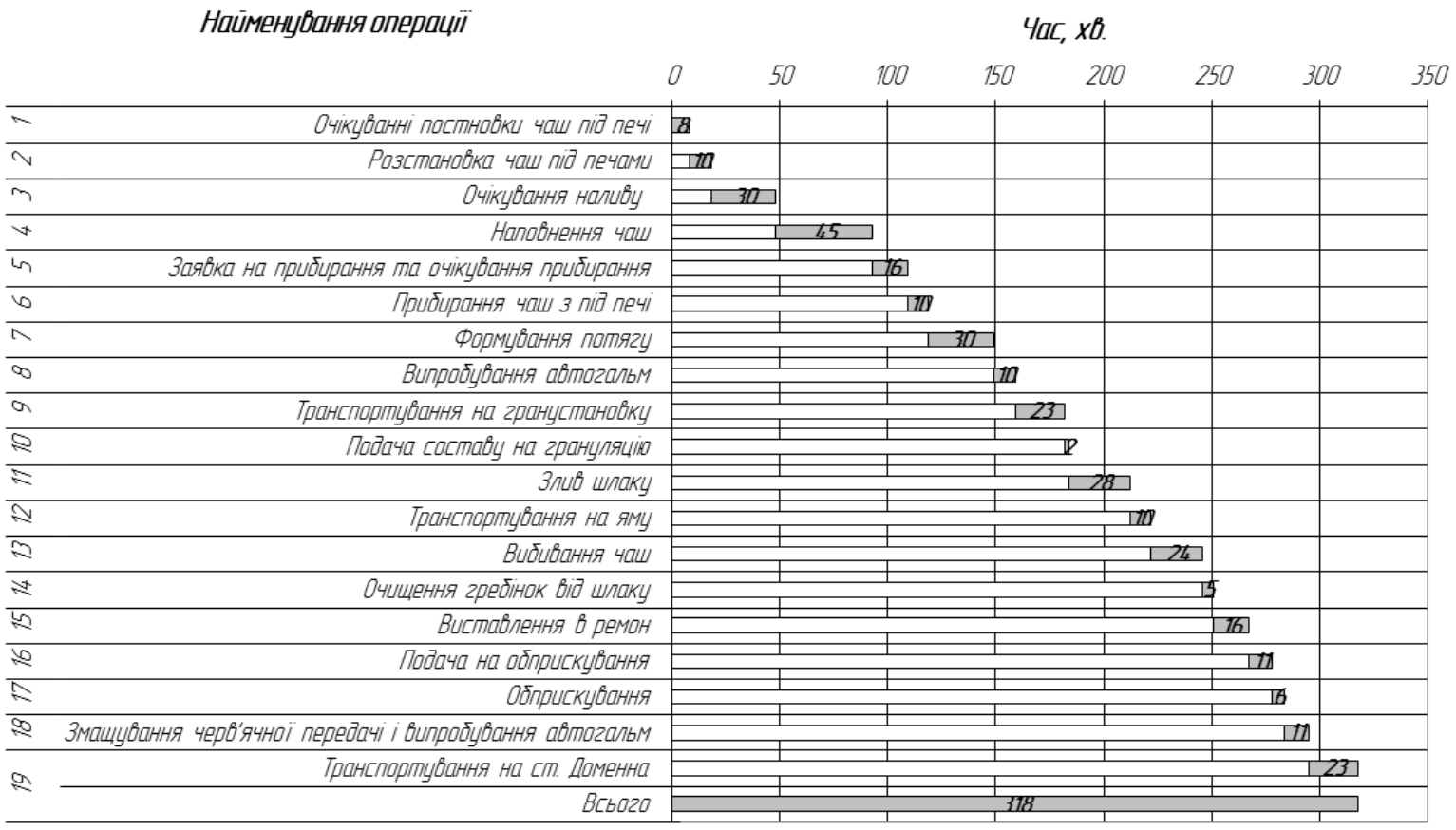

Рисунок 3 - Норматив часу на повний оборот шлакових чаш на ділянці ДЦ-ЦДШ, з урахуванням виконання робіт з виведення і введення в експлуатацію ремонтних шлакових чаш при технічній несправності

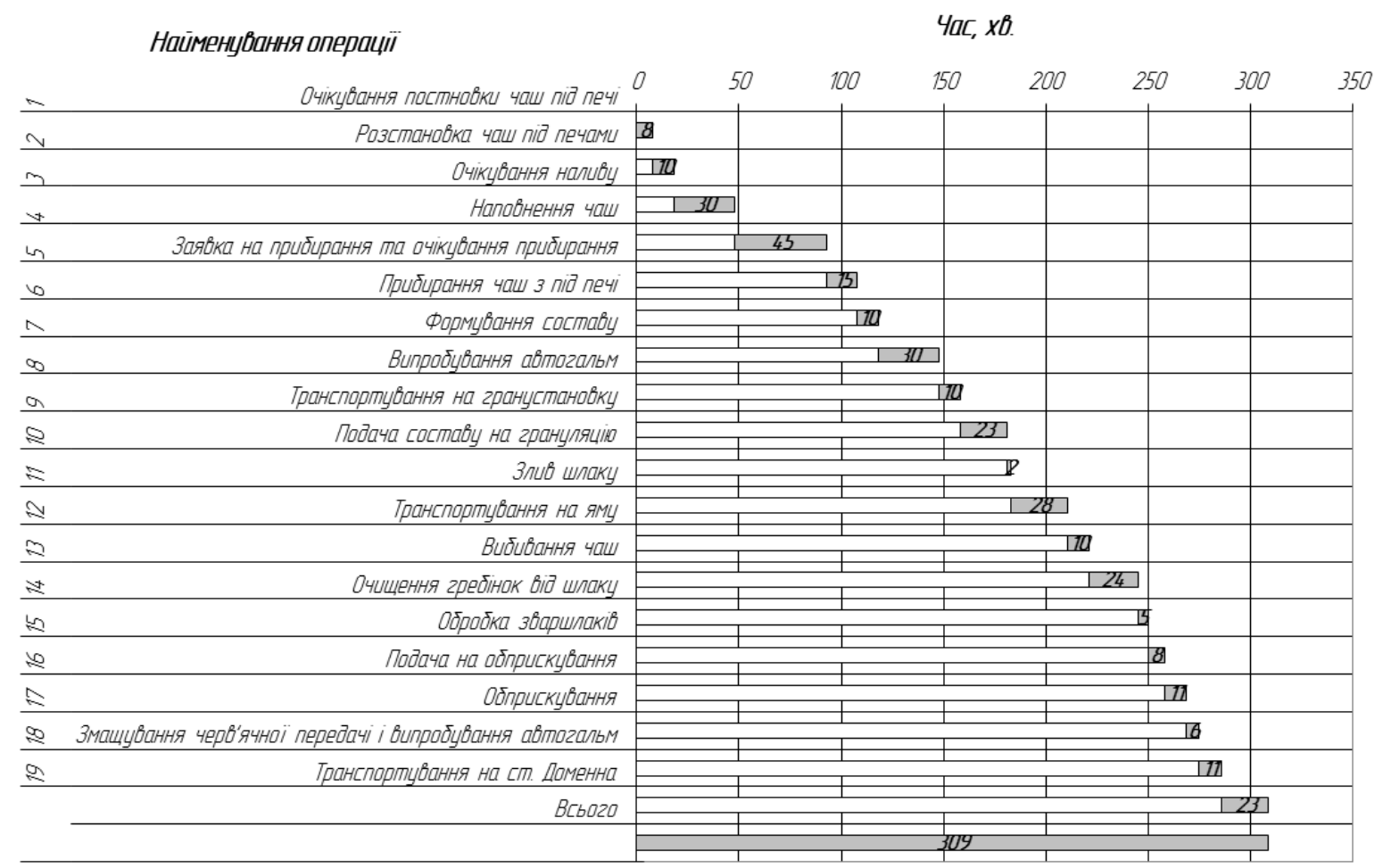

Рисунок 4 - Норматив часу на повний оборот шлакових чаш на ділянці ДЦ-ЦДШ з урахуванням обробки зваршлаків

Режим доступу: http://sap.pstu.edu 
2019 p.

\section{Транспортні технології}

Вип. 20

На рис. 5 наведені схеми транспортно-технологічного циклу транспортування рідкого доменного шлаку в ЦДШ. Переривчастою лінією позначені найбільш поширені простої шлаковозів (шлаковозних составів).
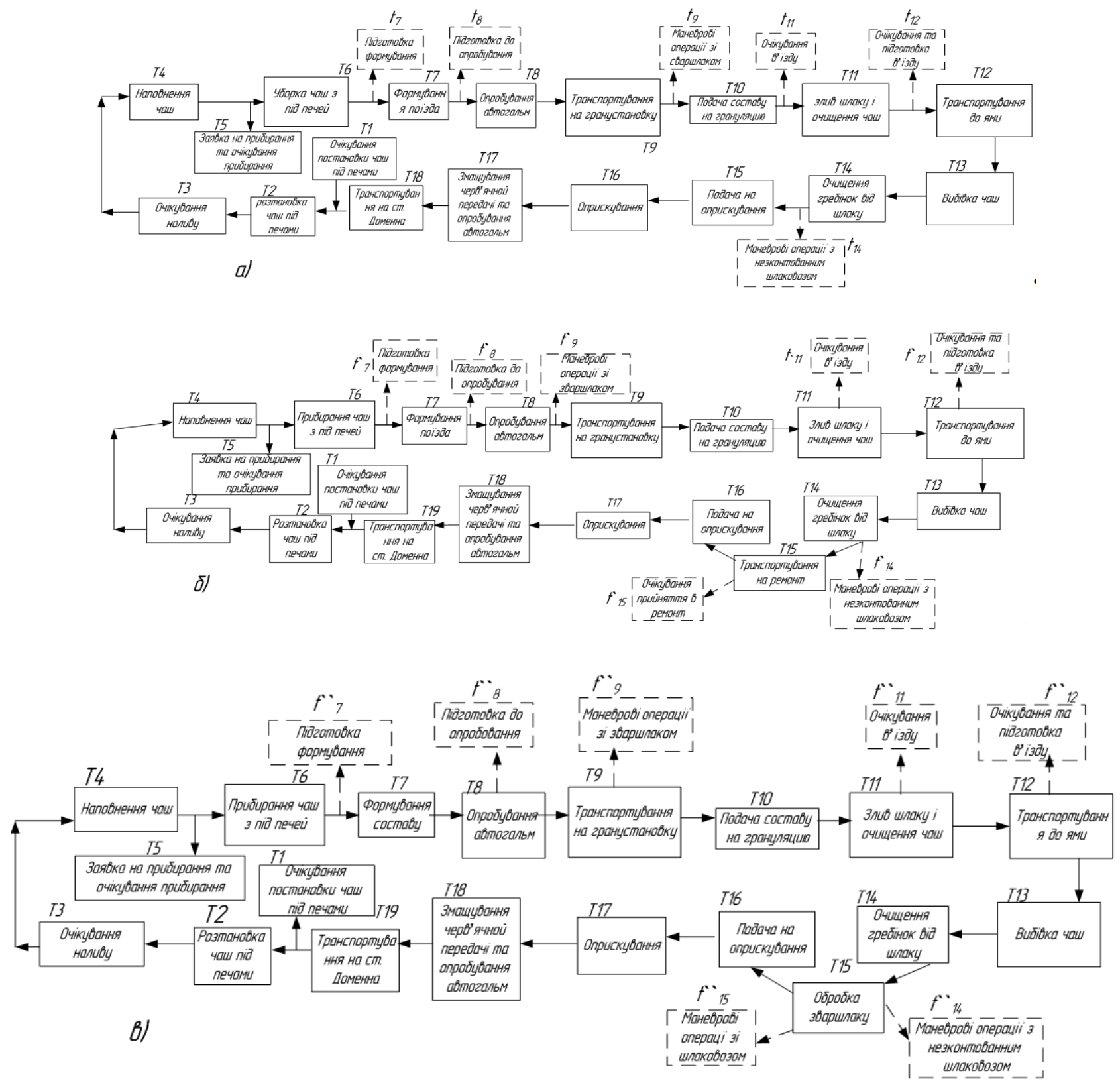

a - без виконання робіт з виведення і введення в експлуатацію ремонтних шлакових чаш і обробки зваршлаків; б - 3 урахуванням виконання робіт 3 виведення і введення в експлуатацію ремонтних шлакових чаш при технічній несправності; в - з урахуванням обробки зваршлаків

Рисунок 5 - Транспортно-технологічні цикли транспортування рідкого доменного шлаку на ділянці ДЦ-ЦДШ

Режим доступу: http://sap.pstu.edu 
$2019 \mathrm{p}$.

\section{Транспортні технології}

Вип. 20

Технологічні цикли оборотів представлені у вигляді математичних моделей, 3 урахуванням додаткових простоїв, отримують вигляд:

$$
\begin{aligned}
& T_{\text {об }}^{l}=\left(T_{1}^{1}+T_{2}^{1}+T_{3}^{l} \ldots+T_{18}^{l}\right)+\left(t_{1}+t_{2}+\ldots+t_{6}\right)=\sum_{i=1}^{18} T_{i}^{l}+\sum_{j=1}^{6} t_{j}, \\
& T_{\text {об }}^{2}=\left(T_{1}^{2}+T_{2}^{2}+T_{3}^{2} \ldots+T_{19}^{2}\right)+\left(t_{1}^{\prime}+t_{2}^{\prime}+\ldots+t_{7}^{\prime}\right)=\sum_{i=1}^{19} T_{i}^{2}+\sum_{j=1}^{7} t_{j}^{\prime}, \\
& T_{\text {об }}^{3}=\left(T_{1}^{3}+T_{2}^{3}+T_{3}^{3} \ldots+T_{19}^{3}\right)+\left(t_{1}^{\prime \prime}+t_{2}^{\prime \prime}+\ldots+t_{7}^{\prime \prime}\right)=\sum_{i=1}^{19} T_{i}^{3}+\sum_{j=1}^{7} t_{j}^{\prime \prime},
\end{aligned}
$$

де $t_{j} ; t_{j}^{\prime} ; t_{j}^{\prime \prime}$ - відповідно тривалості незапланованих операцій і ненормативних простоїв для 3-х графіків обороту шлаковозних составів, що представлені на рис. 2-4.

Діапазони значень фактичних показників часу в порівнянні 3 нормативними

\begin{tabular}{|c|c|c|c|c|c|c|}
\hline \multirow[t]{2}{*}{ Операції } & \multicolumn{3}{|c|}{$\begin{array}{c}\text { Час за } \\
\text { нормативом, хв. }\end{array}$} & \multicolumn{3}{|c|}{$\begin{array}{l}\text { Фактичний час виконання при } \\
\text { несприятливих умовах, хв. }\end{array}$} \\
\hline & 1-й & 2-й & 3-й & $1-и ̆$ & 2 2-й & 3-й \\
\hline Очікування постановки чаш під печі & 8 & 8 & 8 & $7-9$ & $7-9$ & $7-9$ \\
\hline Розстановка чаш під печами & 10 & 10 & 10 & 10 & 10 & 10 \\
\hline Очікування наливу & 30 & 30 & 30 & $29-30$ & $29-30$ & $29-30$ \\
\hline Наповнення чаш & 45 & 45 & 45 & $30-45$ & $30-45$ & $30-45$ \\
\hline $\begin{array}{l}\text { Заявка на прибирання та очікування } \\
\text { прибирання }\end{array}$ & 15 & 16 & 15 & 15 & 16 & 15 \\
\hline Прибирання чаш з під печі & 10 & 10 & 10 & 10 & 10 & 10 \\
\hline Формування составу & 30 & 30 & 30 & $30-40$ & $30-40$ & $30-40$ \\
\hline Випробування автогальм & 10 & 10 & 10 & $10-15$ & $10-15$ & $10-15$ \\
\hline Транспортування на гранустановку & 23 & 23 & 23 & 23 & 23 & 23 \\
\hline Подача составу на грануляцію & 2 & 2 & 2 & 2 & 2 & 2 \\
\hline Злив шлаку & 28 & 28 & 28 & $28-36$ & $28-36$ & $28-36$ \\
\hline Транспортування на яму & 10 & 10 & 10 & $10-13$ & $10-13$ & $10-13$ \\
\hline Вибивання чаш & 24 & 24 & 24 & 24 & 24 & 24 \\
\hline Очищення гребінок від шлаку & 5 & 5 & 5 & $5-8$ & 5 & 5 \\
\hline Виставлення в ремонт & - & 16 & - & - & $16-20$ & - \\
\hline Обробка зваршлаків & - & - & 8 & - & - & $8-12$ \\
\hline Подача на обприскування & 11 & 11 & 11 & 11 & 11 & 11 \\
\hline Обприскування & 6 & 6 & 6 & 6 & 6 & 6 \\
\hline
\end{tabular}
значеннями наведені в табл. 1 .

Таблиця 1 - Порівняння нормативних показників з фактичними

Режим доступу: http://sap.pstu.edu 
Продовження таблиці 1

\begin{tabular}{|l|c|c|c|c|c|c|}
\hline $\begin{array}{l}\text { Змащення черв'ячної передачі і } \\
\text { випробування автогальм }\end{array}$ & 11 & 11 & 11 & 11 & 11 & 11 \\
\hline Транспортування на ст. Доменна (ДЦ) & 23 & 23 & 23 & 23 & 23 & 23 \\
\hline Всього & 301 & 318 & 309 & $301-331$ & $318-349$ & $309-340$ \\
\hline
\end{tabular}

Як видно 3 табл. 1 фактичні значення показників часу (тривалості технологічних операцій) від нормативних значень відрізняються не суттєво. В процесі транспортного обслуговування шлаковозної сторони спостерігаються окремі випадки, коли фактичне значення тривалості деякої операції перевищує нормативне. В той же час фактичне значення тривалості інших операцій навпаки, нижче нормативних. Це пов'язано з цілим рядом чинників. Слід зазначити, що додаткові простої безпосередньо залежать від роботи виробничих агрегатів i можуть виникати під дією як транспортних, так i виробничих факторів. Виробничі пов'язані з порушенням технології виробництва, а транспортні - 3 порушенням організації транспортного обслуговування.

3 урахуванням вищесказаного, треба відмітити, що зміна та корегування нормативів тривалості технологічних операцій до суттєвого підвищення ефективності всього процесу транспортного обслуговування шлаковозної сторони, привести не може.

Такий стан справ призводить до того, що організація взаємодії доменного цеху i залізничного транспорту за жорстким нормативним графіком, в даний час, $\epsilon$ неефективним.

Для вдосконалення транспортно-технологічного циклу доставки чавуну необхідні нові підходи в управлінні та форми організації взаємодії, що дозволяють забезпечувати мінімальні витрати транспорту.

\section{ВИСНОВКИ}

1. Розроблено транспортно-технологічний цикл транспортування рідкого доменного шлаку в цех (відділення) переробки шлаків. Встановлено, що фактична тривалість (час) обороту шлакових ковшів (составів) складається 3 нормативної тривалості виконання технологічних операцій і ненормативних міжопераційних простоїв.

2. Проаналізовано значення непродуктивних і ненормативних простоїв в обороті шлаковозних составів. Встановлена частка даних простоїв відносно загального часу обороту.

3. Відхилення значень фактичних показників від нормативних, не призводять до суттєвого ускладнення процесу транспортного обслуговування за рахунок того, що вони практично повністю компенсуються зниженням часу інших операцій.

4. Проведено перший етап системного аналізу процесу транспортного обслуговування доменного виробництва. Створено передумови для виконання подальших досліджень 3 питань підвищення ефективності взаємодії доменного виробництва і транспорту.

\section{Список використаних джерел:}

1. Лукьянов, В.А. Методика оптимизации взаимодействия промышленного транспорта и основных производств предприятий черной металлургии: дис. .... канд. техн. наук : 05.22 .01 / Лукьянов Вадим Александрович. - СПб, 2003. - 155 с.

2. Попов, A. T. Оптимизация взаимодействия технологического железнодорожного транспорта и производства : автореф. дис. ... канд. техн. наук : 05.22 .12 / Попов Алексей Иванович. - М., 1984. - 24 c. 
$2019 \mathrm{p}$.

\section{Транспортні технології}

Вип. 20

3. Коробкин, A. B. Совершенствование технологии внутриузловых перевозок жидкого чугуна в вагонах-миксерах: дис. .... канд. техн. наук : 05.22.12 / Коробкин А. B. Новосибирск, 1984. - 259 с.

4. Ошурков, B. A. Концепция автоматизированной системы мониторинга транспортировки жидкого чугуна $н$ м металлургических предприятиях / B.A. Ощурков, Л. С. Цуприк, К. В. Бурмистров, И. С. Бурмистрова // Современные проблемы транспортного комплекса России. - 2015. - Вып. 1 (6). - С. 7-11.

5. Емельянова, Н. Ю. Информационная модель системы мониторинга процесса транспортировки жидкого чугуна / Н. Ю. Емельянова, В.А. Емельянов // Системи обробки інформації : зб. наук. праць. - Харків, 2012. - Вип. 2 (100). - С. 37-41.

6. Емельянова, Н. Ю. Информаџионная технология процесса перевозки жидкого чугуна / Н. Ю. Емельянова, В. А. Емельянов // Системи обробки інформації : зб. наук. праць.Харків, 2010. - Вип. 9 (90). - С. 32-36.

Жилинков А. А.

\section{АНАЛИЗ ТРАНСПОРТНО-ТЕХНОЛОГИЧЕСКОГО ЦИКЛА ТРАНСПОРТИРОВКИ ЖИДКОГО ДОМЕННОГО ШЛАКА В ОТДЕЛЕНИЕ ПЕРЕРАБОТКИ}

В связи с развитием современных высокопроизводительных технологий в металлургии и необходимостью учета новых требований, разработаны транспортнотехнологические ичкль доставки жидкого доменного шлака в цеех (отделение) переработки шлаков и выполнен анализ общего времени оборота шлаковозных составов. Определень фактические величины показателей основных технологических операций, которые сопоставлены с нормативными значениями. Выявлены недостатки в транспортном обслуживании шлаковозной сторонь доменного производства. Анализом установлено, что фактическая продолжстельность (время) оборота илаковозных ковщей (составов) состоит из нормативной продолжительности выполнения технологических операций $u$ ненормативных межсоперационных простоев.

Также проанализированы значения величин непродуктивных и ненормативных простоев в обороте илаковозных составов. Установлено прочентное соотношение продолжсительности нормативных и ненормативных простоев в общем времени оборота. Отклонения значений фактических показателей от нормативных практически не приводят $\kappa$ усложнению процесса транспортного обслуживания и увеличению ресурсов транспорта (вагонного и локомотивного парка, путевого развития, численности работников и др.) за счет взаимной компенсации различных временных показателей.

Данная работа является первым этапом системного анализа процесса транспортного обслуживания доменного производства. Создань предпосылки для выполнения дальнейших исследований по вопросам повышения эффективности взаимодействия доменного производства и транспорта, снижение транспортных расходов и себестоимости производства

Ключевые слова: доменное производство, доменная печь, транспортнотехнологическая схема, жидкий доменный илак, промышленный железнодорожный транспорт, илаковоз, норматив времени, оборот подвижного состава, продолжительность технологических операџий, транспортное обслуживание, 
$2019 \mathrm{p}$.

\section{Транспортні технології}

Вип. 20

транспортно-технологический

иикл транспортирования, ненормативные

nростоu,

непроизводительные простои.

Zhylinkov O. O.

\section{ANALYSIS OF THE TRANSPORT-TECHNOLOGICAL CYCLE OF TRANSPORTATION OF LIQUID BLADE SLAG INTO THE WORKSHOP OF BLAST FURNACE SLAG}

In connection with the development of modern high-performance technologies in metallurgy and the need to take into account new requirements, transport-technological cycles for the delivery of liquid blast furnace slag to the slag processing department have been developed and an analysis of the total turnover time of slag trains has been performed. The actual values of indicators of the main technological operations are determined, which are compared with standard values. The deficiencies in the transport service of the slag side of the blast-furnace production are revealed. The analysis established that the actual duration (time) of the turnover of slag-carrying ladles (compositions) consists of the standard duration of the technological operations and non-standard inter-operation idle times.

Also analyzed are the values of unproductive and non-standard downtime in the turnover of slag carriages. The percentage of the duration of regulatory and non-regulatory downtime in the total turnover time was established. Deviations of the actual indicators from the standard practically do not lead to complication of the process of transport service and increase in the transport resources (carriage and locomotive fleet, track development, number of employees, etc.) due to mutual compensation of various time indicators.

This work is the first stage of the system analysis of the process of transport services for the domain production. Prerequisites have been created for further research on improving the efficiency of interaction between blast-furnace production and transport, reducing transport costs and production costs.

Keywords: blast-furnace production, blast furnace, transport and technological scheme, liquid iron, industrial railway transport, hot-metal transfercar, time standard, rolling stock turnover, duration of technological operations, transport service, transport and technological delivery cycle, non-normative downtime, non-productive idle time

Рецензент: проф., д-р техн. наук Парунакян В. Е.

Стаття надійшла 10.02.2019.

УДК 669.013.002.5:639.4

Бейгул О. А., Грищенко Д. И., Бейгул В. О.

\section{ФОРМИРОВАНИЕ НАГРУЗОК И ОПРЕДЕЛЕНИЕ ПАРАМЕТРОВ БУГЕЛЬНОЙ НЕСУЩЕЙ СИСТЕМЫ СОЧЛЕНЕННОГО КОНТЕЙНЕРОВОЗА НА ПНЕВМОКОЛЕСНОМ ХОДУ}

Разработана математическая модель формирования внешних нагрузок, восприятия $и$ передачи внутренних усилий в силовых элементах бугельной несущей системы сочлененного контейнеровоза на пневмоколесном ходу, в основу которой положены три расчетных случая: движение на горизонтальном участке технологической дороги; формирование самоуравновешенных боковых сил, изгибающих лонжероны и поперечину бугельной рамы $в$

Режим доступу: http://sap.pstu.edu 